\title{
TRANSANAL MINIMALLY INVASIVE SURGERY FOR TOTAL MESORECTAL EXCISION (ETM) THROUGH TRANSANAL APPROACH (TAETM) WITH ROBOTIC AND TRANSANAL ENDOSCOPIC OPERATIONS (TEO) COMBINED ACCESS: STEP BY STEP SURGERY
}

Operação minimamente invasiva transanal para excisão total do mesorreto (ETM) através de acesso transanal (TaETM) com uso da robótica e de Operações Endoscópicas Transanais (TEO) combinadas: passo a passo do procedimento

Carlos Ramon Silveira MENDES, Marcus VALADÃO, Rodrigo ARAÚJO, Eduardo LINHARES, José Paulo JESUS

From the Instituto Nacional de Câncer INCA (Cancer National Institute - INCA), Rio de Janeiro, RJ, Brazil.

HEADINGS - Surgical procedures. Minimally invasive. Robotics. Natural orifice endoscopic surgery. Surgical procedures. Operative.
ABSTRACT - Rational: In the treatment of colorectal cancer, from 1982 Heald proposed standardization of the total mesorectal excision, with a significant reduction in the recurrence rate. But the treatment of lower rectal lesions is still a challenge. Aim: To describe the association of robotic low anterior resection- TATA (Transanal Abdominal Transanal Resection), with transanal access using Transanal Endoscopic Operations - TEO in the treatment of lower rectal cancer. Method: The TATA performs robotic abdominal approach and the TEO performs the perineal approach, developing total mesorectal excision (TME) transanally (TaETM). Result: The TaETM technique was applied in a woman with rectal adenocarcinoma $5 \mathrm{~cm}$ from the anal verge that had been submitted to chemoradiation. The procedure was performed with satisfatory operative time and favorable oncological outcome (grade 3 mesorectal excision). Conclusion: This is a promising minimally invasive procedure in the armamentarium of rectal cancer treatment, specially in challenging scenarios such as narrow pelvis, obesity and very low rectal tumors.

\section{Correspondence: \\ Carlos Ramon Silveira Mendes \\ E-mail: proctoramon@hotmail.com \\ Financial source: none \\ Conflicts of interest: none}

Received for publication: 19/12/2014

Accepted for publication: 09/02/2015

DESCRITORES - Procedimentos cirúrgicos minimamente invasivos. Robótica. Cirurgia endoscópica por orifício natural. Procedimentos cirúrgicos operatórios.
RESUMO - Racional: No tratamento do câncer colorretal, a partir de 1982 Heald propôs padronização da excisão total do mesorreto, com redução importante no índice de recidivas. Apesar disso, o tratamento das lesões do reto inferior ainda permanecem um desafio. Objetivo: Descrever a associação da abordagem robótica por via abdominal - TATA (Transanal Abdominal Transanal Resection), com o acesso transanal utilizando o Transanal Endoscopic Operations TEO no tratamento do câncer de reto inferior. Método: A TATA realiza o tempo abdominal por robótica e o TEO o tempo perineal, desenvolvendo a excisão total do mesorreto (ETM) por via transanal (TaETM). Resultado: A técnica TaETM foi aplicada em mulher com adenocarcinoma de reto a $5 \mathrm{~cm}$ da margem anal que tinha sido submetida à radioquimioterapia. $O$ procedimento foi realizado com um tempo cirúrgico satisfatório bem como resultado oncológico favorável (ressecção mesorretal grau 3). Paciente obteve alta no segundo dia pós-operatório com seguimento ambulatorial satisfatório. Conclusão: Trata-se de um procedimento minimamente invasivo bastante promissor no arsenal terapêutico do câncer de reto, principalmente em situações de maior dificuldade técnica como pelve estreita, obesidade e lesões do reto distal.

olorectal cancer is a serious health problem worldwide. It is known that $25 \%$ of cases are located in the rectum ${ }^{9,11}$. Since 1982 , Heald et al. proposed standardization of the total mesorectal excision (TME), whose initial results were surprising in terms of local recurrence ${ }^{9}$. From this standardization on, there was decrease in local recurrence to less than $10 \%$ and increased overall survival of $80 \%$ with the cylindrical excision of the specimen. However, despite the best results achieved, the treatment of lower rectal tumors were still a challenge, since maintaining the quality of life is clearly related to the sphincter preservation.

Adequately performed TME (grade III mesorectal excision) associated with the need of sphincter preservation in low rectal tumors has stimulated the search for new tactics and techniques.

The transanal endoscopic microsurgery (TEM, English Transanal Endoscopic Microsurgery) was introduced in 1983 by G. Buess as minimally invasive technique for resection of adenomas and early rectal carcinomas $2,14-20$.

The TATA technique (Transanal Abdominal Transanal Resection) described by Marks et al. ${ }^{12-13}$ provided better quality of life for patients who were to undergo abdominoperineal amputation, making possible to perform laparoscopically. Using the TATA technique, while performing laparoscopic abdominal and perineal step with the TEO (Transanal Endoscopic Operations - Storz, Tuttlingen, Germany) was suggested by excision mesorectal transanally (TaETM).

This article aims to describe the association of the abdominal robotic approach 
with transanal access using the TEO in the treatment of lower rectal cancer

\section{METHODS}

\section{Technique}

Under general anesthesia, begins the abdominal approach using the Da Vinci Si robot. Trocars uses the following provision: 1) camera positioned right of the umbilicus $(3 \mathrm{~cm}$ to the right and $2 \mathrm{~cm}$ above the umbilicus); 2 ) arm 1 in the right iliac fossa; 3) arm 2 positioned to the left of the camera portal (8 to 10 $\mathrm{cm}) ; 4)$ arm 3 in the left iliac fossa $(8-10 \mathrm{~cm}$ away from the gate arm portal 2); and 5) other portal to use the arm 3 located in the midline between the xiphoid process and the umbilicus . The auxiliary portal is located in the right upper quadrant, equidistant from the camera portal and arm 1 (Figure 1)

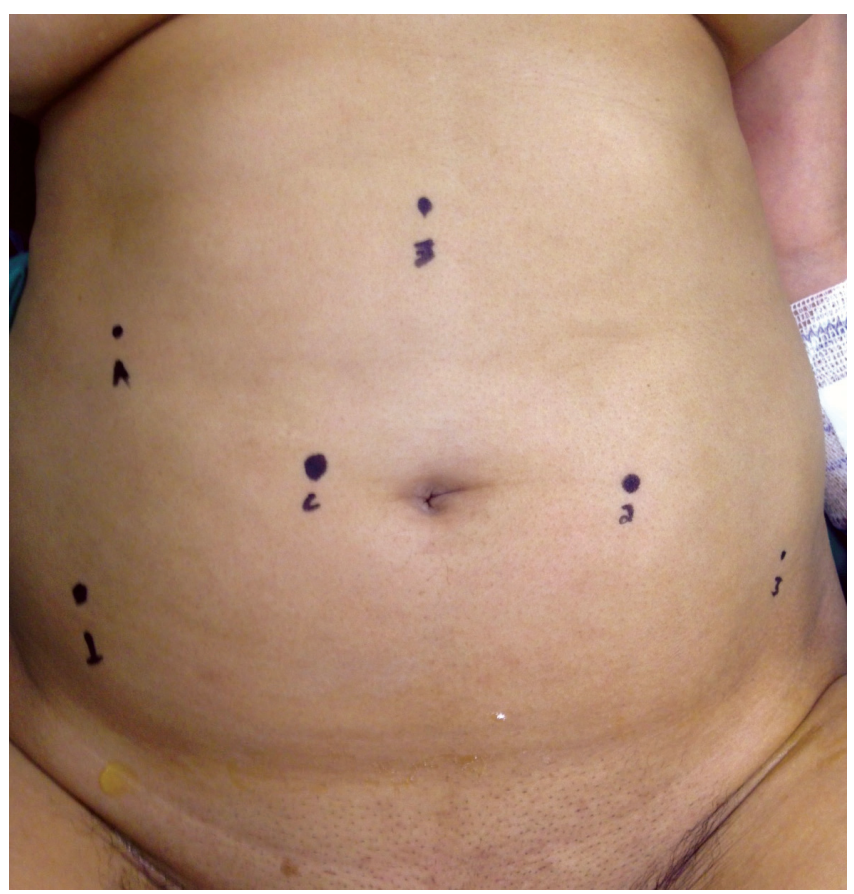

\section{FIGURE 1 - Arrangement of trocars}

After completion of the pneumoperitoneum, the robotic trocars are introduced as mentioned. The patient is placed in the Trendelenburg position and lateral tilt right . Robotic docking is performed in an oblique manner in the patient's left side (Figures 2 and 3).

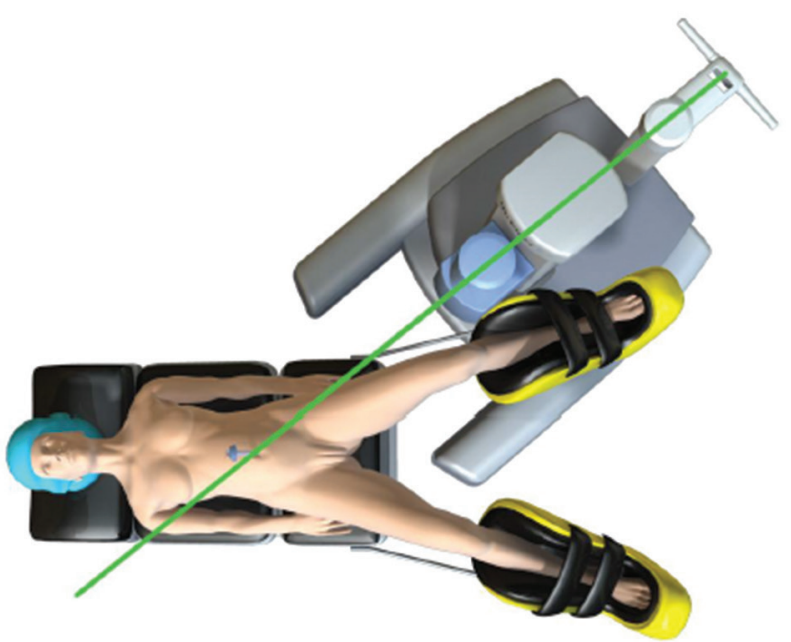

FIGURE 2 - Diagonal robotic docking

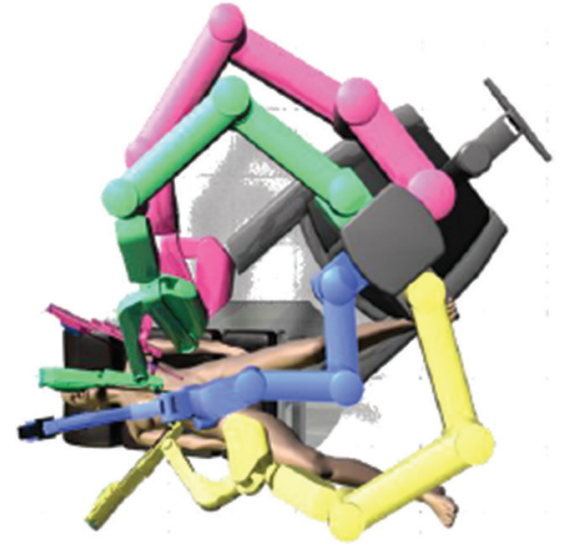

FIGURE 3 - Position of the robotic arms

Initially, only arm 1 (scissors and monopolar energy) and arm 3 in the midline portal (bipolar forceps) are used together with an auxiliary port that is used by the surgeon in the operating field. Arm 2 is left undocked. Medial to lateral approach is performed for left colon dissection.

The procedure begins with retroperitoneal dissection using the inferior mesenteric vein with a tent to reach the parietocolic gutter. Ligation of the vein and inferior mesenteric artery at its origin. Then is made the release of the colon of the parietocolic gutter and the complete take down of the splenic flexure. It is certified that the colon is with good mobility for a low colorectal anastomosis and then is performed the pelvic approach with robotic mesorretal excision.

Pelvic approach requires the docking of the arm 2 as described above and the change of the arm 3 position from the middle line to the port located on the left iliac fossae. Dissection of the mesorectal is performed using three arms and the arm 3 is used to expose the pelvic structures and dissection is performed with arms 1 and 2 . The mesorretal dissection is followed until the beginning of the extraperitoneal rectum.

From that point, transanal approach begins with the use of TEO (Figure 4). Anal digital expansion is performed for TEO system introduction, pneumoreto is held with 12 $\mathrm{mmHg}$ of pressure, exposition of the dentate line and tumor identification.

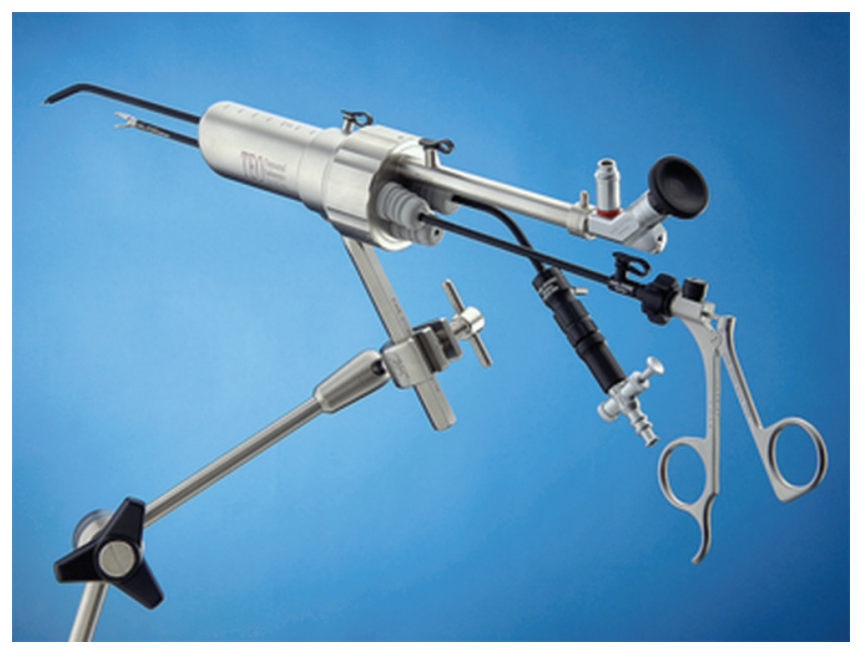

FIGURE 4 - Transanal Endoscopic Operations - TEO (Storz, Tuttlingen, Germany)

Distal margin of resection is defined from $2 \mathrm{~cm}$ of the tumor, making purse string suture to close the rectal stump using $3.0 \mathrm{Vicryl}{ }^{\circledR}$. After a circumferential demarcation of the 
rectum with the use of monopolar electrocautery, dissection proceeds to the avascular posterior portion to the pre-sacral fascia, completing the circumferential dissection by mesorectal approach until the peritoneal reflection and reaching the robotic dissection.

Surgical specimen is removed transanally. After extraction of the specimen and colon section was performed purse string suture and a $33 \mathrm{~mm}$ circular stapler head is attached and returned the colon into the abdominal cavity. A robotic pouch suture of the rectal stump was performed to proceed the anastomosis with the $33 \mathrm{~mm}$ stapler. The TEO was held for revision of the anastomosis (integrity assessment with the tire repairman test, and evaluation of the presence of bleeding). The procedure was completed with the construction of a protective colostomy and placement of pelvic drain.

\section{RESULT}

This procedure was applied in a patient undergoing anterior resection of the rectum, combining abdominal robotic approach and the transanally completion of mesorretal excision using the TEO.

The clinical data and diagnosis of the case were: 55 year-old woman, hypertensive, with rectal adenocarcinoma 5 $\mathrm{cm}$ from the anal margin with colonoscopy showing a rectal tumor located $5 \mathrm{~cm}$ from the anal verge, occupying $40 \%$ of the rectal lumen. Magnetic resonance imaging (Figure 5) showed left posterolateral tumor (T3N1M0).

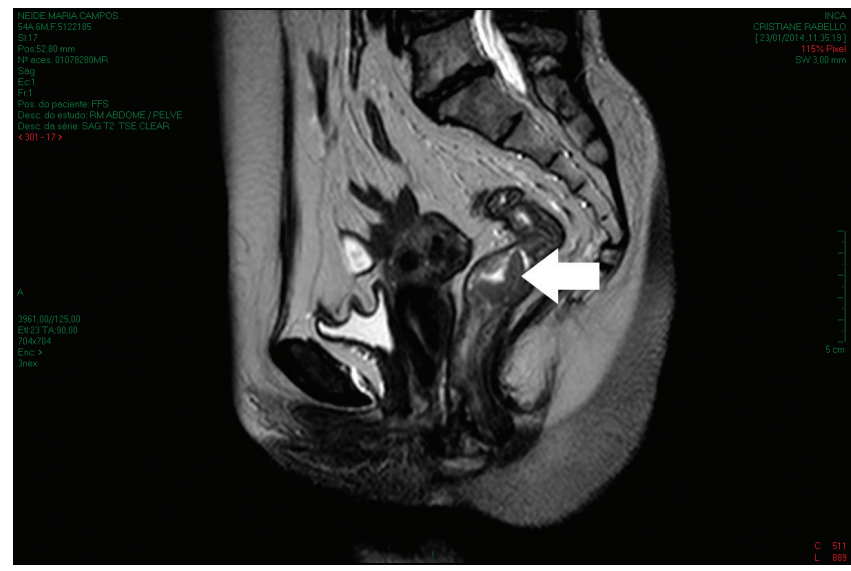

FIGURE 5 - MRI lesion pretreatment T3N1M0

Patient underwent radiotherapy (50,4Gy) combined with chemotherapy (5 -FU) ending in May 2014 with good response (Figure 6). The pre-neoadjuvant CEA was 3.1 and after 1.1.

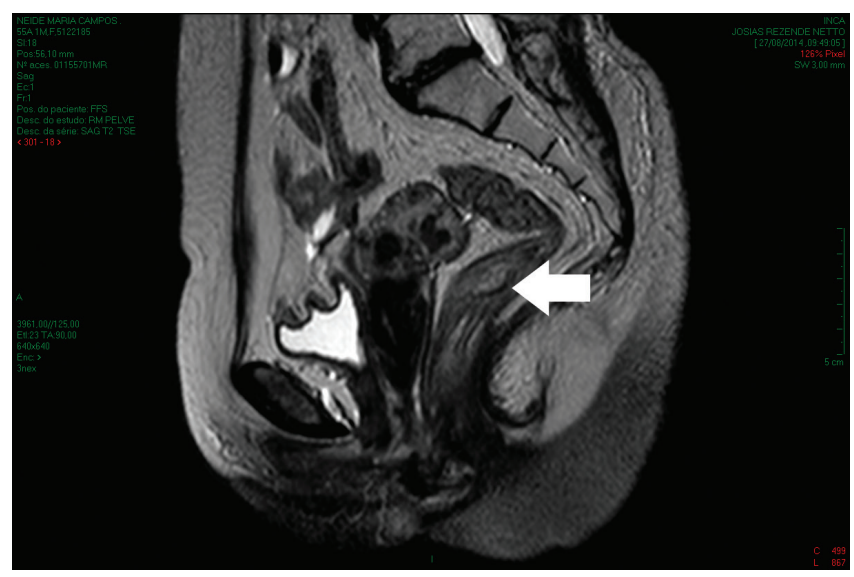

FIGURE 6 - MRI after neoadjuvant therapy (radiation and chemotherapy)
The patient was submitted to the procedure as described (rectal resection combining robotic and TEO approach).

The patient presented good postsurgical recovery and was discharged on the second day after the procedure. Patient is followed in the outpatient office with no complaints. Ostomy closure was scheduled.

\section{DISCUSSION}

To authors' knowledge, this is the first report in the literature of the use of this combination.

Factors such as obesity, narrow pelvis, fatty mesorectum, postchemoradiation, limit laparoscopically resection. Thus, the TaETM is an alternative to difficult cases. It is technique that combines the abdominal access to release the splenic flexure of the colon, inferior mesenteric artery and vein ligation and mesorectal pelvic dissection - as distal as possible - with transanal access. This access is performed by a circumferential incision and dissection around the rectum, through the mesorectum toward the abdominal cavity. At this step, the abdominal dissection meet the perineal dissection.

Many advances have been achieved in the treatment of rectal cancer in recent decades. Among them it can be mentioned the use of neoadjuvant radiochemotherapy in the treatment of locally advanced extraperitoneal rectal cancer; standardization of mesorectal excision technique; improved imaging (high resolution resonance); development of techniques for transanal resection of early tumors; and use of minimally invasive techniques (laparoscopy and robotics) ${ }^{22-25}$. Despite all these advances, the treatment of lower rectal cancer still represents a great challenge because the minimally invasive resection should be associated with the appropriate mesorectal excision and sphincter preservation. Accordingly, laparoscopic approach, although providing faster postoperative recovery ${ }^{3}$, still presents technical limitations, especially in lesions that require ultra-low resection.

The use of robotic surgery in rectal cancer overcame these limitations by laparoscopy (especially in difficult pelvic dissection situations, such as man, obesity, low rectal tumors and narrow pelvis $)^{5}$. The articulation of the instruments, camera stability, the quality of the 3D image and the dexterity of movement, are all factors contributing to more precise mesorectal dissection and easier the way to dissect in difficult anatomical situations.

Despite the gain with robotics in terms of mesorectal dissection, the section of the rectum in ultra-low resection is still a challenge, because the use of stapler in android pelvis is not always possible due to the difficulty of achieving the ideal angulation to the distal section.

The use of TEO in order to perform transanally mesorectal dissection has gained prominence in recent years ${ }^{4}$, especially in ultra-low resection. The advantages would be more likely to remain in the distal sphincter injury, since the transanal display provides greater security in the identification of the distal end section and the most appropriate mesorectal dissection. Since its first use in 2010 for the purpose of mesorectal dissection in combination with laparoscopic access ${ }^{24}$, some centers have been using this promising technique. The rational of the transanal dissection is to offer a greater chance of sphincter preservation in addition to providing more adequate oncologic resection. This was evidenced by Denost et al. that demonstrated superiority of cancer results in cases of rectal cancer below $6 \mathrm{~cm}$ from the anal verge treated with transanally mesorectal dissection compared to only abdominal laparoscopic approach?

The combination of the two techniques described (robotics and TEO) adds the most advantageous features of each mode: the accuracy and ease of mesorectal dissection in more difficult pelvis in which laparoscopy has limitations associated with greater likelihood of sphincter preservation with the transanal dissection using the TEO. 
This pioneering experience of the authors was very positive, because it allowed grade III mesorectal excision combined with sphincter preservation. In the authors' opinion, the combination of these two techniques can provide many benefits to patients with rectal cancer whose ultra-low resection is necessary. There is no doubt that this unprecedented combination may represent useful strategy in the routine treatment of rectal cancer.

More procedures should be performed in order to establish the role of this approach in ultra-low rectal cancer as the standard treatment.

\section{CONCLUSION}

The transanally total mesorectum excision using the TEO associated with the robotic abdominal approach have shown to be a safe procedure with excellent oncologic result. This new approach proved to be extremely useful in middle and low rectal tumors after neoadjuvant therapy and specially in technical challenging situations such as narrow pelvis, obesity and ultra-low rectal tumors, in which laparoscopic staplers have limited use.

\section{REFERENCES}

1. Atallah SB, Albert MR, deBeche-Adams TH, Larach SW. Robotic transanal minimally invasive surgery in a cadaveric model. Tech Coloproctol 2011; 15:461-464.

2. Araujo SEA. Transanal endoscopic microsurgery: a Brazilian initial experience in provate pratice. Hepato-Gastroenterology. 2012; 59:118.

3. Aziz O, Constantinides V, Tekkis P et al. Laparoscopic versus open surgery for rectal cancer: A meta-analysis. Ann Surg Oncol 2006; 13: 413-424.

4. Araujo $S E, C$ rawshaw $B$, Mendes CR, Delaney CP. Transanal total mesorectal excision: a systematic review of the experimental and clinical evidence. Tech Coloproctol 2014,

5. Balli C, Ziogas D, Roukos D, Baltogiannis G. Laparoscopic and robotic rectal câncer resection: Expectations for improving oncological outcomes. Ann Surg 2010; 251: 185.

6. Bhattacharjee HK, KirschniakA, Storz P, Wilhelm P, KunertW. Transanal endoscopic microsurgery-based transanal acess for colorectal surgery: experience on humano cadavers. J Laparoendosc Adv Surg Tech. 2011; 21:835-840.

7. Denost Q, Adam JP, Rullier A, Buscail E, Laurent C, Rullier E. Perineal Transanal Approach. A new standard for laparoscopic sphinctersaving resection in low rectal cancer, a randomized trial. Ann Surg 2014; 260: 993-999

8. Han Y, He YG, Zhang Hb, Ly KZ, Zhang YJ, Lin MB, Yin L. Total laparoscopic sigmoid and rectal surgery in combination with transanal endoscopic microsurgery: a preliminar evaluation in China. Surg Endosc. 2013; 27:518-524.

9. Heald RJ, Husband Em, Ryall PD. The mesorectum in rectal câncer surgery - the clue to pelvic recorrence? Br j Surg. 1982; 69(10): 613-16.

10. Lacy AM, Rattner DW, Adelsdorfer C, Tsende MM, Fernandez M, Delgado S, Sylla P, Martinez-Palli G. Transanal natural orifice trasnluminal endoscopic surgery (NOTES) rectal resection: "downto-up"total mesorectal excision (TME)- short-term outcmes in the first 20 cases. Surg Endosc 2013

11. Landis Sh, Muray T, Bolden S, Wingo Pa. Cancer Statistics, 1999. CA Cancer J Clin. 199:49(1): 8-31
12. Marks GJ, Marks JH, Mohiuddin M, Brady L. Radical sphincterpreserving surgery with coloanal anastomosis following high-dose external irradiation for the very low lying rectal câncer. Recent results Cancer Res. 1998; 146:161-174.

13. Marks J, Mizrahi B, DalaneS, Nweze I, Marks G. Laparoscopic transanal abdominal transanal resection with sphincter preservation for rectal câncer in the distal $3 \mathrm{~cm}$ of the rectum after neoadjuvant therapy. Surg Endosc 2010; 24:2700-2707

14. Mc Lemore EC, Coker AM, Devaraj B, Chakedis J, Maawy A, jnui T, Talamini MA, Horgan S, Peterson MR, Sylla P, Ramamoorthy S. TAMIS - assisted laparoscopic low anterior resection with total mesorectal excison in a cadaveric series. Surg Endosc. 2013

15. Moore JS, Cataldo PA, et al. Transanal endoscopic microsurgery is more effective tha traditional transanal excision for resection of rectal masses. Dis colon e rectum. 2008; 51: 1026-1031

16. Moraes RS, Malafaia O, et al. Microcirurgia endoscópica transanal no tratamento dos tumores do reto: estudo prospectivo em 50 pacientes. Arq Gastroenterol. 2008; 45(4): 268-274.

17. Moraes RS, Zanchet MV, Sobottka WH, Lima JHF, Morgenstern GA, Malafaia O, Buess G, Coelho JCU. Qualidade de vida do paciente submetido à Microcirurgia Endoscópica Transanal (TEM). ABCD Arq Bras Cir Dig 2007;20(1):34-7.

18. Moraes RS, Buess G, Lima JHF, Morgenstern GA, Schulz GJ, Campos $A C L$, Coelho JCU. Transanal endoscopic microsurgery (TEM) in the treatment of postoperative colorectal stenosis. ABCD Arq Bras Cir Dig 2008;21(3):147-9

19. Moraes RS, Sobottka WH, Zanchet MC, Lima JHF, Morgenstern GA, Schulz GJ, Buess G, Malafaia O, Coelho JCU. Custo comparado da Microcirurgia Endoscópica Transanal(TEM)coma retossigmoidectomia anterior e com a cirurgia de amputação abdômino-perineal do reto. ABCD Arq Bras Cir Dig 2007;20(3):150-3

20. Moraes RS, Losso GM, Matias JEF, Mailaender L, Telles JEQ, Malafaia O, Coelho JCU. Microcirurgia endoscópica transanal e tratamento adjuvante no câncer retal precoce. ABCD Arq Bras Cir Dig 2011;24(2): 113-120

21. Nahas SC, Nahas CSR, et al. Transanal endoscopic microsurgery (TEM): a minimally invasive procedure for treatment of selected rectal neoplasms. Arq Bras Cir Dig. 2010; 23(1): 35-39.

22. Rouanet $P$, Mourregot A, Azar CC, Carrere S, Gutowski M, Quenet F, Saint-Aubert B, Colombo PE. Transanal Endoscopic Protectomy: An Innovative Procedure for Difficult Resection of Rectal Tumors in Men with Narow Pelvis. Dis Colon Rectum 2013; 56: 408-415.

23. Sylla P, Sohn DK, Cizqiner S, Turner BG, Gee DW, Willingham FF, Hsu M, Mino-Kenudson M, Brugge Wr, Rattner DW. Survival study of natural orifice transluminal endoscopic surgery for rectosigmoid resection using transanal endoscopic microsurgery with or without transgastric endoscopic assistance in swine model. Surg Endosc 2010; 24(8): 2022-2030.

24. Sylla P, Rsttner DW, Delgado S, Lacy AM. Notes transanal rectal câncer resection using transanal endoscopic microsurgery and laparoscopic assistance. Surg Endosc 2010; 24: 1205-1210

25. Sylla P, WillinghamFF, Sohn DK, Gee D, Brugge WR, Rattner DW. NOTES rectosigmoid resection using transanal endoscopic microsurgery (TEM) with transgastric endoscopic assistance: a pilot study in swine. J Gastrointest Surg 2008; 12(10):1717-1723.

26. Telen DA, Berger DL, Bordelanou LG, Rattner DW, Sylla P. Update on Transanal NOTES for Rectal Cancer: Transitioning to Human Trials. Minimally Invasive Surgery 2012.

27. Trunzo JA, Delaney CP. Natural orifice proctectomy using a transanal endoscopic microsurgical technique in a porcine model. Surg Innov 2010; 17(1): 48-52

28. Velthuis S, van den Boezem PB, van der Peet DL, Cuesta MA, Sietses C. Feasibility study of transanal total mesorectal excision. BJS 2013. 